\title{
Prevention of protein deficiency in dairy bull calves during fattening
}

\author{
E L Kharitonov ${ }^{1}, K S$ Ostrenko $^{1,2, *}, V O$ Lemiasheuski $^{1,2}$, and $V P$ Galochkina $^{1}$ \\ ${ }^{1}$ All-Russian Research Institute of Physiology, Biochemistry and Animal Nutrition - Branch of the \\ Federal Science Center for Animal Husbandry named after Academy Member L. K. Ernst, \\ Moskovskoe sh. 55a, Tyarlevo Settlement, Saint Petersburg, 196625, Russia \\ ${ }^{2}$ International Sakharov Environmental Institute of Belarusian State University, 23/1 Dolgobrodskaya \\ Street, Minsk, 220070, Belarus
}

\begin{abstract}
The problem of low-quality protein in the diet of animals leads to excessive formation of a by-product (ammonia) in the rumen, which is not involved in the synthesis of microbial protein. The aim of the study is to develop a method for the prevention of protein deficiency in dairy bull calves. Bull calves of Kholmogorsk breed were grown in the vivarium of Institute under the controlled feeding and keeping conditions from 40 days of age to 14 months. Milk replacer feeding was carried out up to 70 days of age with free access to mixed feed and hay.In order to study the effect of concentrated feeds on metabolic processes and digestibility of nutrients, rumenal digestion factors were studied. It was found that physiological and biochemical parameters fit into reference values. The use of concentrated feed together with strict proportional administration of roughage during intensive growing and fattening of bull calves of dairy breeds makes it possible to reach an average daily increase of up to $1420 \mathrm{~g}$ by the age of 14 months and effectively pay for the feed with the productsupon the normal course of enzymatic processes in the rumen and throughout the body.
\end{abstract}

\section{Introduction}

Productivity, disease resistance, as well as the programmed ability to reproduce, which have been planned on the basis of a complete identification of the animal's genetic capabilities, are possible only when all the necessary nutrient, mineral, and biologically active substances are fed into the body and the energy demand is complete. The balanced feeding is the provision of all the necessary nutrients in the diet and the delivery of the necessary classes of nutrients including vitamins and minerals in optimal proportions. Depending on the combination, primarily of the protein components of the feed, a protein component is provided, which is the main material in the constructive metabolism for a rapidly developing organism. In the transition to intensive forms of animal husbandry, it is necessary to supply the protein deficit by feeding with protected protein and normalizing the functioning of cicatricial digestion.

\footnotetext{
*Corresponding author: ostrenkoks@gmail.com
} 
Standardized nutrition provides for the accounting of the required quantity and quality of protein in feed. The problem of low-quality protein in the diet, which is used in animal husbandry, is characterized by a high content of metabolized protein, which leads to the excessive formation of a by-product (ammonia) in the rumen that is not involved in the synthesis of microbial protein and excreted in the urine with additional energy costs. This disturbance leads to an overspending of fodder protein and is accompanied by metabolic disorders, deterioration of the animal's health and leads to higher production costs. An unbalanced diet, especially of young calves, leads to the development of all kinds of rumen pathologies and impedes the implementation of pedigree qualities.

In intensively growing bull calves as well as in cows, one of the factors limiting the intensity of the processes of biosynthesis of meat components is the amount of glucose and amino acids coming from the gastrointestinal tract to the metabolic pool [1-2]. Apart from that, the problem of not only the profitable beef production, but also its quality should be solved. The result can be achieved if the attitude to the production of beef is not only as the production of by-products of animal husbandry with an average daily gain of 500-550 g and the delivery of bull calves to a meat-processing plant with a live weight of $330-350 \mathrm{~kg}$, but also as a highly efficient and profitable production [3-5].

In countries with a high development of cattle breeding (USA, Argentina, and European countries), it was proved that technological feeding of Holstein bull calves requires an increase in energy demand of $10 \%$ to maintain their body compared with Aberdeen-Angus bulls. However, at the stage of growing-finishing, bull calves of dairy breeds use the energy of the diet for the formation of muscle tissue with less accumulation of fat more efficiently [5-6]. Thus, dairy bull calves are economically beneficial to be fed with a high energy content (concentrated feed) diets and, to a lesser extent, roughage. A deficiency in protected protein is characterized by the signs of digestive upset, causes atony of the rumen, and leads to a sharp reduction in the number of ciliates. The destruction of amino acids occurs with the formation of harmful proteinogenic amines (histamine, tyramine, and cadaverin), the absorption of which contribute to the development of laminitis. The alkaline reaction of the medium is accompanied by the inhibition of the function of ciliates, symbiontic bacteria, their death, violation of fermentation processes in the pancreas. Putrefactive microorganisms are developing intensively, the concentration of ammonia to $25 \mathrm{mg} / 100 \mathrm{ml}$ and more (normal 5-20) increases in rumen. A lack of protein is accompanied by a decrease in productivity, immunity, natural and non-specific resistance of the body, and the development of alimentary dystrophy.

When fattening bull calves, the negative consequences of high-protein concentrated feeding should be considered, i.e., consuming high-energy food, animals are at a constant risk of acidosis. Therefore, strict control is necessary in the development of technology and the adherence to the stages of feeding. It is shown that when using the nutrition system of bull calves of the dairy breeds, taking into account the peculiarities of digestion and metabolism, by $12-14$ months of age it is possible to achieve a live weight of $400-450 \mathrm{~kg}$ with good quality meat products. Thus, the development and implementation of a nutritional system for growing and fattening bull calves of dairy breeds will make a significant contribution to the fight against rumen pathologies and increase their productivity [7-8].

The aim of the study is to develop an optimal calculation of the consumption of protected protein, which allows to completely provide the growing organism of the animal with protein, which is a guarantee of the future potential for health and productivity and an obstacle to the development of rumen pathologies. 


\section{Materials and methods}

The bull calves of Kholmogorsk breed were grown in the vivarium of All-Russian Research Institute of Physiology, Biochemistry and Animal Nutrition under the controlled feeding and keeping conditions from 40 days of age to 14 months. The group is made up of 7 livestock units. Milk replacer feeding was carried up to 70 days of age with free access to the balanced feed and hay. In the post-dairy period, bull calves received balanced feed, hay and silage taking into account the eatability (table 1).

Table 1. Food intake and nutritional intake (actual eatability).

\begin{tabular}{|c|c|c|c|}
\hline \multirow{2}{*}{ Indicators } & \multicolumn{3}{|c|}{ Age } \\
\cline { 2 - 4 } & $\begin{array}{c}4 \text { months } \\
\text { gain in weight } \\
1300 \mathrm{~g}\end{array}$ & $\begin{array}{c}9.5 \text { months } \\
\text { gain in weight } 1340 \mathrm{~g}\end{array}$ & $\begin{array}{c}14 \text { months } \\
\text { gain in weight } \\
1420 \mathrm{~g}\end{array}$ \\
\hline Hay, kg & 1 & 0,5 & 1,0 \\
\hline Balanced feed, kg & 4,5 & 4,25 & 5,4 \\
\hline Grass silage, kg & - & 6,0 & 12 \\
\hline \multicolumn{4}{|c|}{ The diet contains } \\
\hline Metabolizable energy, MJ & 55 & 60,9 & 89 \\
\hline Dry matter, kg & 5,1 & 6,1 & 9,9 \\
\hline Crude protein, g & 950 & 924 & 921 \\
\hline Degradable protein, g & 705 & 655 & 422 \\
\hline Non-degradable protein, g & 258 & 269 & 728 \\
\hline Metabolizable protein, g & 480 & 502 & 1815 \\
\hline Crude fat, g & 155 & 194 & 5848 \\
\hline Crude fiber, g & 470 & 923 & \\
\hline Nitrogen-free extractive & 3270 & 4059 & \\
\hline substances, g & \multicolumn{3}{|c|}{} \\
\hline
\end{tabular}

The energy level and feed composition were determined with the generally accepted physiological, biochemical, and zootechnical methods.

To study the effect of concentrated feed on metabolic processes and digestibility of nutrients in the rumen, a series of laboratory studies was performed. The control points of 4, 9.5, 14 months of age were determined when the indices of cicatricial digestion were studied. Five cicatricial fluid samples were taken after feeding. The resulting content of the rumen was run through 2 layers of gauzy fabric.

Laboratory studies of the enzymatic activity of microflora of the animal rumen were carried out using glass capillaries (in vitro). A study of the amilolytic ability of microorganisms in relation to "pure" nutrients considering such indicators as cellulolytic and amylolytic activity was conducted. Cotton thread № 10 and $20 \%$ potato starch solution were taken as the sources of nutrients. The value of the enzymatic activity was judged by the decrease in the length of the column in the capillary of nutrient sources, which were expressed as a percentage. Cellulolytic activity was evaluated in accordance with V. I. Georgievsky's method (1976) by the difference in the weight of the threads before and after incubation. The incubation time was 36 hours. At the same time, an effort was made to reconstruct the natural conditions for the development of microorganisms (nutrient intake, constant t $38-39{ }^{\circ} \mathrm{C}$, anaerobic conditions, imitation of rumen motility, and $\mathrm{pH}$ control). Quantitative indicators of rumen microbiocenosis were determined in the Goryaev chamber for 15-20 min from the time of collection; the number of ciliates and the total number of bacteria in $1 \mathrm{ml}$ of the contents, their enzymatic activity, mobility and acidity $(\mathrm{pH})$ of the medium were calculated with a pH meter OHAUS Starter ST2100-B.

VFA (volatile fatty acids) analysis 
VFA analysis were performed by gas chromatography (GC) (6890 N, Agilent, Santa Clara, CA, USA), equipped with an HP - INNOWax column and a flame ionization detector. To analyze the VFA, $5 \mathrm{ml}$ of slurry sample, $25 \%$ phosphoric acid solution and $1 \mathrm{ml}$ of saturated mercury solution (Sigma-Aldrich, St. Louis, Mo., USA) were taken into a $15 \mathrm{ml}$ tube and then the solution was centrifuged at $3134 \mathrm{x} \mathrm{g}$ for $20 \mathrm{~min}$. Thereafter, $1 \mathrm{ml}$ of the supernatant was centrifuged at $13,800 \mathrm{x} g$ for $10 \mathrm{~min}$ and filtered through a $0.2 \mu \mathrm{m}$ filter (Whatman, Uppsala, Sweden). The filtrates were placed in $2.0 \mathrm{ml} \mathrm{GC}$ vials (Agilent, Santa Clara, Calif., USA) to measure the concentration of volatile fatty acids by GC. $0.2 \mu \mathrm{Lwas}$ the sample injection volume with a split ratio of 10:1. The temperature of the oven started from $80^{\circ} \mathrm{C}$, and then initially increased by $20^{\circ} \mathrm{C}$ per minute and kept at $120^{\circ} \mathrm{C}$ for $2 \mathrm{~min}$, then the temperature was upgraded to $205^{\circ} \mathrm{C}$ by increasing $10{ }^{\circ} \mathrm{C}$ per minute, finally, it was maintained at $205^{\circ} \mathrm{C}$ for $2 \mathrm{~min}$. The injection and detection ports were maintained at $250{ }^{\circ} \mathrm{C}$.

Ammonia was determined by the microdiffusion method in Conway dishes.

The statistical significance of the obtained values of the studied parameters was evaluated using the Wilcoxon-Mann-Whitney U-test.

\section{Results}

A study of metabolic indices in the rumen shows that intensively growing bull calves are characterized by a high level of enzymatic and microbiological processes (table 2).

Table 2. Indicators of enzymatic and microbiological processes in the rumen of bull calves of different ages $(\mathrm{M} \pm \mathrm{m}, n=5)$.

\begin{tabular}{|c|c|c|c|}
\hline \multirow{2}{*}{ Indicators } & \multicolumn{3}{|c|}{ Age } \\
\hline & 4 months & 9.5 months & 14 months \\
\hline Weight indicators, $\mathrm{kg}$ & $156 \pm 0,76$ & $381,9 \pm 1,86$ & $553,8 \pm 4,12$ \\
\hline Daily gain, $\mathrm{g}$ & $1300 \pm 43$ & $1340 \pm 64$ & $1420 \pm 87$ \\
\hline $\mathrm{pH}$, unit & $6,3 \pm 0,14$ & $6,8 \pm 0,02^{1}$ & $7,1 \pm 0,04^{1,2}$ \\
\hline Ammonia, $\mathrm{mg} \%$ & $12,3 \pm 0,78$ & $6,4 \pm 0,98^{1}$ & $7,8 \pm 0,55^{1}$ \\
\hline VFA, mmol/100ml & $16,0 \pm 1,79$ & $8,6 \pm 0,38^{1}$ & $8,9 \pm 0,27^{1,2}$ \\
\hline Acetate, $\%$ & $58,2 \pm 1,52$ & $68,5 \pm 0,44^{1}$ & $71,3 \pm 1,01^{1,2}$ \\
\hline Propionate, $\%$ & $30,7 \pm 2,02$ & $16,8 \pm 0,31^{1}$ & $15,5 \pm 0,55^{1}$ \\
\hline Butyrate, \% & $11,0 \pm 1,93$ & $14,6 \pm 0,18^{1}$ & $13,0 \pm 0,57^{2}$ \\
\hline The number of bacteria, billion $/ \mathrm{ml}$ & $8,3 \pm 0,32$ & $9,73 \pm 0,06$ & $9,7 \pm 0,18$ \\
\hline The number of ciliates, thousand $/ \mathrm{ml}$ & $429 \pm 6,6$ & $688 \pm 17,7$ & $615 \pm 22,5^{1,2}$ \\
\hline Amylolytic activity, units/ml & $30,3 \pm 0,96$ & $28,7 \pm 0,65$ & $34,3 \pm 0,35^{2}$ \\
\hline Cellulolytic activity, \% & $5,3 \pm 0,39$ & $5,0 \pm 0,27$ & $10,4 \pm 0,39^{1,2}$ \\
\hline \multicolumn{4}{|c|}{ Hereinafter, a significant difference is $\mathrm{p}<0.05$ to the corresponding age } \\
\hline
\end{tabular}

The study determined no significant deviations from physiological norms indicating that a high-concentrate type of feeding does not cause disturbances in the microbiocenosis of the rumen during the growing of bulls. Towards the end of the feeding period, an increase in cellulolytic and amylolytic activity is observed, which correlates with the total increase in microbiota activity.

Biological features of the young organism are rapid growth and lower consumption of nutrients per unit of increase in live weight [9-10]. With age, the efficiency of the use of nitrogen and energy expectedly decreases but remains 1.5-2 times higher than not only in extensive, semi-intensive, or intensive growing, but also at a more mature age. 


\section{Discussion}

Ruminant animals are known to have fundamental differences in the physiology of digestion and metabolism. Due to the enzymatic activity of microorganisms, not only the quantitative, but also the qualitative characteristics of almost all feed components change. Microbiological processes in the pancreas modify the amount and composition of the amino acids of the feed, and the carbohydrates of the feed turn into VFA. Higher fatty acids are synthesized from non-lipid components, and significant changes occur in the fatty acid composition of feeds [11-13]. Anaerobic organisms have the ability to hydrolyze cellulose and other nutrients. An important feature of metabolism of ruminant animals is the processes of protein breakdown and synthesis in the pancreas, which have a decisive influence on the provision of their body with protein and amino acids. Depending on the quantity and quality of the protein in the diet, the pancreatic microorganisms can turn a significant part of the protein into ammonia, and it will be excreted from the body in the form of urea, or a biologically complete microbial protein can be synthesized from the nonprotein part of the protein. However, the high ability of ruminants to symbiotic digestion, like any other, makes them easily vulnerable not only to environmental stresses but also to fluctuations in the nutritional value of the diet, which is especially noticeable in the early periods of the formation of rumen microbiota. Microbial protein synthesis can satisfy the needs of only low-productivity animals (in dairy cows, it is up to $3000 \mathrm{~kg}$ of milk per lactation). In highly productive bull calves with a high productivity potential and growth rate, the part of the complete fodder protein should avoid decay in the rumen and enter the small intestine [14-15]. Strict adherence to the technology of fattening dairy bull calves allows physiologically competent formation of the microbiocenosis of the rumen, which in the future will allow the efficient use of concentrated feed energy and give high gain weight.

In many farms, it is not always possible to comply with the required technology for the preparation and storage of feed and to balance the diets properly; therefore, it is difficult to provide animals with complete feeds. This causes the disturbance of the established balance of symbiotic microorganisms (suppliers of nutrients) and, as a result, a decrease in productivity.

When attached to food substrates, symbiont bacteria of the rumen secrete enzymes that destruct the plant fragments, disrupting the cellulose molecule, separating side chains and hydrolyzing the remaining oligosaccharides. Cellulolytic bacteria are sensitive to $\mathrm{pH}$ changes (in this regard, an increase in the content of starch and sugars leads to a decrease in $\mathrm{pH}$ to 5.8 units, and fiber fermentation is inhibited). During the studies, it was found that the addition of hay and silage to concentrated feeds does not make it possible to $\mathrm{pH}$ decrease with the active breakdown of concentrates and the release of a great amount of oligosaccharides [16-19]. This balance helps to provide the body of bull calves with energy not only to maintain metabolism, but also to super-maintain the growth. Throughout the feeding, the $\mathrm{pH}$ level was within the physiological norm. The reaction of the medium containing the rumen is an important factor determining the state of enzymatic processes, the formation of metabolites, their absorption and use in the body. It should be noted that the $\mathrm{pH}$ value of the scar content depends on many factors, including the fractional composition of the protein. In our studies, it was found that with a decrease in protein cleavability in diets, the indicator of the concentration of hydrogen ions in the scar content of animals of the experimental groups tended to increase the acidity. Concentrated feed containing a high level of protected protein becomes inaccessible to rumen proteolytic microorganisms, which is accompanied by a decrease in protein breakdown and leads to less formation of its breakdown products and increases bioavailability for the macroorganism. 
Amylolytic bacteria, hydrolyzing starch, do not break the cellulose down, but they ferment dextrins and maltose; however, these bacteria are not able to use most mono- and disaccharides as a substrate. They are less sensitive to $\mathrm{pH}$ although they significantly affect the ratio of VFA. The rate of starch degradation in the rumen depends on the type of feed and its processing [20-21]. Saccharolytic bacteria also ferment simple soluble sugars (unlike hydrolysis of starch grains and fiber, the adhesion mechanism is not involved). Starch undergoes hydrolytic cleavage with the formation of various dextrins, from which maltose is formed, and then glucose. In the rumen, starch is easily fermented with the formation of volatile and non-volatile fatty acids. An increase in amylolytic activity during the experiment indicates a high intensity of metabolic processes and an increase in gross energy, which is one of the main factors of growth intensification.

Fermentation of soluble sugars can occur regardless of bacterial growth. Some types of cicatricial bacteria are proteolytic and break down the soluble proteins, amino acids and peptides with the formation of ammonia [22-23]. The concentration of ammonia formed in the rumen is determined primarily by the quantity and quality of feed protein and nitrogencontaining non-protein compounds, as well as the intensity of its absorption and use for de novo protein synthesis. A decrease in ammonia in the rumen indicates an intensification of the reactions of direct amination of keto acids with ammonia as the main way of microbial amino acid synthesis [24-25].

\section{Conclusions}

The development of an optimal calculation of the consumption of protected protein allows providing the growing organism of the animal with protein, promising the future potential for health and productivity and preventing the development of rumen pathologies.

The analyzed physiological and biochemical parameters fit into the reference values. The highly concentrated type of feeding does not cause disturbances in the rumen microbiocenosis during the growing of bull calves. By the end of stage 3 , an increase in cellulolytic and amylolytic activity was observed, which correlates with the total increase in microbiota activity and contributes to improved health and, as a result, daily weight gains. The use of concentrated feed for intensive growing and fattening of bull calves of dairy breeds makes it possible to reach an average daily increase of up to $1420 \mathrm{~g}$ by the age of 14 months and effectively pay for the feed with the products upon the normal course of enzymatic processes in the rumen and throughout the body. This area has a high profitability especially in the regions with a large livestock of dairy cattle and low prime cost of concentrated feed.

\section{References}

1. Galochkin V A, Ostrenko K S, Galochkina V P, Fedorova L M 2018 The relationship of the nervous, immune, endocrine systems and nutritional factors in the regulation of animal resistance and productivity Agricultural Biology 53(4), 673-686 Doi: 10.15389 / agrobiology.2018.4.673rus

2. Poghosyan D G, Kharitonov E L, Ramazanov I G 2008 The effect of barohydrothermal processing of grain on the quality of protein in diets for ruminant animals Feed production 12, 23-25

3. Galochkin V A, Galochkina V P, Ostrenko K S 2019 The effect of feed with different levels of metabolic protein on the intensity of the bull-calf growing Effective Livestock, 1(149), 54-56 Doi: 10.24411 / 9999-007A-2019-10008

4. Hancock A S, Younis P J, Beggs D S, Mansell P D, Stevenson M A, Pyman M F 2016 
An assessment of dairy herd bulls in southern Australia: 1 Management practices and bull breeding soundness evaluations J. Dairy Sci. 99(12) 9983-9997 Doi: 10.3168/jds.2015-10493

5. Pérez-Linares C, Bolado-Sarabia L, Figueroa-Saavedra F et al 2017 Effect of immunocastration with Bopriva on carcass characteristics and meat quality of feedlot Holstein bulls Meat Sci. 123 45-49 Doi: 10.1016/j.meatsci.2016.08.006

6. Takemoto S, Tomonaga S, Funaba M, Matsui T 2017 Effect of long-distance transportation on serum metabolic profiles of steer calves Anim. Sci. J. 88(12) 19701978 Doi: 10.1111/asj.12870

7. Devant M, Quintana B, Aris A, Bach A 2015 Fattening Holstein heifers by feeding high-moisture corn (whole or ground) ad libitum separately from concentrate and straw J. Anim. Sci. 93(10) 4903-16 Doi: 10.2527/jas.2014-8382

8. Kučević D, Papović T, Tomović V, Plavšić M, Jajić I, Krstović S, Stanojević D 2019 Influence of Farm Management for Calves on Growth Performance and Meat Quality Traits Duration Fattening of Simmental Bulls and Heifers Animals (Basel.) 9(11) Doi: 10.3390/ani9110941.

9. Ardicli S, Samli H, Vatansever B, Soyudal B, Dincel D, Balci F 2019 Comprehensive assessment of candidate genes associated with fattening performance in HolsteinFriesian bulls Arch. Anim. Breed. 62(1) 9-32 Doi: 10.5194/aab-62-9-2019

10. He Y, Qiu Q, Shao T et al 2017 Dietary Alfalfa and Calcium Salts of Long-Chain Fatty Acids Alter Protein Utilization, Microbial Populations, and Plasma Fatty Acid Profile in Holstein Freemartin Heifers J. Agric. Food Chem. 65(50) 10859-10867 Doi: 10.1021/acs.jafc.7b04173

11. Kharitonov E L 2019 The processes of cicatricial digestion in bull calves during the periods of growing and fattening at different levels of metabolic protein in the diet Problems of the biology of productive animals 4 64-72

12. Niu W, He Y, Wang $\mathrm{H}$ et al 2018 Effects of Leymus chinensis replacement with whole-crop wheat hay on blood parameters, fatty acid composition, and microbiomes of Holstein bulls J. Dairy Sci. 101(1) 246-256 Doi: 10.3168/jds.2017-13267

13. Soulat J, Picard B, Léger S, Monteils V 2018 Prediction of beef carcass and meat quality traits from factors characterising the rearing management system applied during the whole life of heifers Meat Sci., 140, 88-100 Doi: 10.1016/j.meatsci.2018.03.009

14. Verdú M , Bach A, Devant M 2015 Effect of concentrate feeder design on performance, eating and animal behavior, welfare, ruminal health, and carcass quality in Holstein bulls fed high-concentrate diets J. Anim. Sci. 93(6) 3018-33 Doi: 10.2527/jas.2014-8540

15. Shibata M, Hikino Y, Matsumoto K 2019 Influence of feeding a grass hay diet during the early stage of the fattening period on growth performance, carcass characteristics, and meat production in Japanese Black steers Anim Sci J. 90(2) 196-204 Doi: 10.1111/asj.13139

16. Ha J J, Yang K Y, Oh D Y, Yi J K, Kim J J 2018 Rearing characteristics of fattening Hanwoo steers managed in different stocking densities Asian-Australas J Anim Sci. 31(11) 1714-1720 Doi: 10.5713/ajas.17.0451

17. Broderick G A 2018 Optimizing ruminant conversion of feed protein to human food protein Animal. 12(8) 1722-1734 Doi:10.1017/S1751731117002592

18. Gebreyesus G, Difford G F, Buitenhuis B et al 2020 Predictive ability of host genetics and rumen microbiome for subclinical ketosis J Dairy Sci. 103(5) 4557-4569 Doi:0110.3168/jds.2019-17824 
19. Cui Z, Wu S, Liu S, Sun L 202 From Maternal Grazing to Barn Feeding During Preweaning Period: Altered Gastrointestinal Microbiota Contributes to Change the Development and Function of the Rumen and Intestine of Yak Calves Front Microbiol. 11 485-501 Doi: 10.3389/fmicb.2020.00485.

20. Maneerat W, Prasanpanich S, Tumwasorn S 2015 Evaluating agro-industrial byproducts as dietary roughage source on growth performance of fattening steers Saudi $J$ Biol Sci. 22(5) 580-584 Doi: 10.1016/j.sjbs.2015.01.015

21. Chung C S, Cho W K, Jang I S, Lee S S, Moon Y H 2017 Effects of feeding system on growth performance, plasma biochemical components and hormones, and carcass characteristics in Hanwoo steers Asian-Australas J Anim Sci. 30(8) 1117-1123 Doi:10.5713/ajas.17.0166 